\title{
COMPARATIVE STUDY BETWEEN DEXAMETHASONE AND FENTANYL AS AN ADJUVANT TO BUPIVACAINE IN ULTRASOUND GUIDED SUPRACLAVICULAR BRACHIAL PLEXUS BLOCK IN UPPER LIMB SURGERIES
}

By

\section{Mohsen Badawy Sayed, Saeed Mostafa Abd El-Hameed and Eslam Mohammed Yousef Ahmed}

Department of Anesthesia and Intensive care, Al-Azhar Faculty of Medicine

E-mail: Dr_eslam111@yahoo.com

\begin{abstract}
Background: Brachial plexus block is a popular and widely employed regional nerve block technique for perioperative anesthesia and analgesia for surgery of the upper extremity and supraclavicular approach is the easiest and most consistent method for surgery below the shoulder joint.

Objectives: The aim of this the study was to compare the effect of Bupivacaine plus Dexamethasone versus Bupivacaine plus Fentanyl in ultrasound guided supra-clavicular approach of the brachial plexus block for upper limb surgeries as regards: Onset of the block, duration of the block, postoperative analgesia, and hemodynamic parameters.
\end{abstract}

Patients and Methods: This prospective double - blinded, randomized controlled trial study included 60 patients of both sexes, scheduled for upper limb surgeries (Orthopedic and Plastic surgeries .(

They were divided into two equal groups:

Group 1: (Fentanyl group): Bupivacaine+ Fentanyl.

Group 2: (Dexamethasone group): Bupivacaine + Dexamethasone.

The following parameters were assessed between the two groups: Sensory Block, motor block, time of block, analgesia duration and hemodynamics.

Results: The current study showed that the addition of dexamethasone to bupivacaine for supraclavicular brachial plexus block leads to prolongation of motor and sensory block duration, prolongation of duration of analgesia. Onset of motor and sensory block was shorter in fentanyl group than dexamethasone group.

Conclusion: The addition of dexamethasone to bupivacaine prolonged the time of block and analgesia duration longer than fentanyl. Also, the onset of block was shorter when fentanyl was added to bupivacaine.

Keywords: Complications, surgery, Technique,. Dexamethasone, fentanyl, bupivacaine, brachial, motor, sensory , analgesia, upper limb.

\section{INTRODUCTION}

Regional nerve block minimizes the stress response and using minimal anesthetic drugs is always beneficial for the patients with various comorbidities.
(1) Brachial plexus block is a popular and widely employed regional nerve block technique for perioperative anesthesia and analgesia for surgery of the upper extremity and supraclavicular approach is 
the easiest and most consistent method for surgery below the shoulder joint (ElBaradey and Elshamaa, 2014).

Bupivacaine used frequently for supraclavicular nerve block as it has long duration of action from 3 to $6 \mathrm{~h}$. Adjuvant to local anesthetics for brachial plexus block may enhance the quality and duration of analgesia (Basin et al. 2012).

Brachial plexus blockade reduces pain, but still with limited duration and the challenge remains to increase the duration of analgesia with decreasing side-effects (Laiq et al, 2008).

Different adjuvants have been used to prolong regional blockade, shorten the onset times of blocks and prolonge duration of post-operative analgesia. Various adjuvants, including fentanyl, midazolam, magnesium sulfate, dexamethasone, and neostigmine have been added to local anesthetics in an attempt to increase the duration of block and postoperative analgesia (Yadav et al, 2008).

Fentanyl is a ?-opioid receptor agonist that has been used as an adjuvant to local anesthetics, improving the efficacy of peripheral nerve block.

Dexamethasone is a very potent and highly selective glucocorticoid. Various studies have been done using dexamethasone $8 \mathrm{mg}$ as an adjuvant to local anaesthetics mixture in brachial plexus block resulting in variable effects on onset but prolonged duration of analgesia and motor block (Vieira et al, 2010).

The present study aimed to compare the effect of Bupivacaine plus Dexamethasone versus Bupivacaine plus
Fentanyl in ultrasound guided supraclavicular approach of the brachial plexus block for upper limb surgeries.

\section{PATIENTS AND METHODS}

This Prospective double - blinded, randomized trial study was approved by the ethics committee in Al-Azhar University Hospitals (Al-Hussein and Sayed Galal), and patients' written informed consents were obtained.

This study included 60 patients of both sexes, scheduled for upper limb surgeries (Orthopedic and Plastic surgeries). They were divided to two equal groups:

Group 1: (Fentanyl group): Bupivacaine+ Fentanyl: received 100 mcg Fentanyl +20 $\mathrm{ml}$ bupivacaine $0.5 \%$. Total volume 22 $\mathrm{ml}$.

Group 2: (Dexamethasone group): Bupivacaine + Dexamethasone: received 8 $\mathrm{mg}$ dexamethasone $+20 \mathrm{ml}$ of bupivacaine $0.5 \%$. Total volume $22 \mathrm{ml}$

Preoperative evaluation: Routine preoperative assessment by full history taking, physical examination including chest and heart examination and investigations (CBC, S. creatinine, blood urea, AST, ALT, PT, PTT, INR, ECG, and chest X-Ray).

The comerically available forms of the study drugs that were used:

A $20 \mathrm{ml}$ vial of Bupivacaine $0.5 \%$ (Bupivacaine HCL) equivalent to $5 \mathrm{mg} / \mathrm{ml}$ (sunny pharmaceutical industries).

A $2 \mathrm{ml}$ ampoule of Fentanyl (Fentanyl) equivalent to $50 \mathrm{mcg} / \mathrm{ml}$ (Sunny pharmaceutical industries).

A $2 \mathrm{ml}$ ampoule of dexamethasone 8 mg (Dexamethasone sodium phosphate) 


\section{COMPARATIVE STUDY BETWEEN DEXAMETHASONE AND FENTA... 503}

equivalent to $4 \mathrm{mg} / \mathrm{ml}$ (Amriya Pharm. Ind).

\section{Inclusion criteria:}

- American Society of Anesthesiologist (ASA) class I and II.

- Age 20-60 years of both sexes.

- BMI less than $36 \mathrm{Kg} / \mathrm{M} 2$

\section{Exclusion criteria:}

- Local infection at the site of puncture.

- Patients having any neurologic deficit in the upper limb.

- Patients having history of hematological disorders, including coagulation abnormality.

- Patient has a known allergy to study drugs .

- Refusal to regional anesthesia, anatomical abnormality at the site, peripheral neuropathy.

A successful block were defined as complete sensory and motor blockade in all regions of median, ulnar, and redial nerve distribution and the block were assessed every 2 minutes after local anesthetic injection.

Anesthetic failure in the surgical area was defined if the patient experienced pain during sensory and motor test and this was controlled by IV fentanyl 1-2 $? \mathrm{~g} / \mathrm{kg}$, or recourse to general anesthesia, those patients not included in our study and was replaced by other patients.

Surgical effectiveness was defined as surgery ended without patient discomfort and the need for supplementation of the block.

Assessment of Sensory Block: was assessed by a pin prick test:
Grade 0: normal sensation.

Grade 1: decreased pain sensation to pinprick.

Grade 2: loss of pain sensation to pinprick in the median, ulnar, radial, and musculocutaneous nerve distribution.

The test was done every 5 minutes for 30 minutes before surgery and time of loss of sensation all over the forearm and hand was recorded then every 4 hours till resolution of sensory block or first analgesia rescue and the time was recorded.

Duration of sensory block was defined as the time interval between the success of the block and the complete resolution of anesthesia on all nerves area and it was recorded.

Assessment of Motor block: Motor block was determined by thumb abduction (radial nerve), thumb adduction (ulnar nerve), thumb opposition (median nerve), and flexion of elbow (musculocutaneous nerve) every $5 \mathrm{~min}$ and every $1 \mathrm{~h}$ post operatively according to the modified Bromage scale ( Sari et al,. 2015).

Duration of motor block was defined as the time interval between the success of the block and the recovery of complete motor function of forearm and hand.

Hemodynamic parameters: On arrival to the operating theater, the vital signs parameters including MAP, HR, RR and $\mathrm{SpO} 2$ was recorded at base line and during the time of surgery.

Post-operative settings: At the end of the surgery, the patient was kept under observation postoperatively for 1 hour to monitor vital signs (conscious level, blood 
pressure, heart rate, respiratory rate and pattern) then discharged to ward to be followed for returning of pain.

Side effect and Complication assessment: The patients were observed for the occurrence of any adverse effect and/or complication related to the procedure, nausea, vomiting, and hypoxemia $(\mathrm{SpO} 2<90 \%)$.

Any complications including vascular puncture, horner's syndrome, pneumothorax, and phrenic nerve palsy, was recorded.

Postoperative pain: The assessment of postoperative pain was done hourly in the recovery room and in surgical ward with the help of Numeric Rating Scale (1-10). Zero was considered as no pain, 1-3 as mild pain, 4-6 as moderate pain and 7-10 as severe pain. At score of 4 , rescue analgesic (inj. diclofenac sodium (1.5 $\mathrm{mg} / \mathrm{kg}$ ) iv infusion) was given. Duration of analgesia will be the time from drug injection to the time of first resque of analgesia. Total analgesic dose during first 24 hours will be recorded.

\section{Statistical analysis:}

Recorded data were analyzed using the statistical package for social sciences, version 20.0 (SPSS Inc., Chicago, lllinois, USA). Quantitative data were expressed as meant standard deviation (SD). Qualitative data were expressed as frequency and percentage.

\section{The following tests were done:}

- Independent-samples t-test of significance was used when comparing between two means.

- Mann Whitney U test: for twogroup comparisons in non-parametric data.

- Chi-square (x2) test of significance was used in order to compare proportions between qualitative parameters.

- The confidence interval was set to 95\% and the margin of error accepted was set to $5 \%$. So, the p-value was considered significant as the following:

$\mathrm{P}$-value $<0.05$ was considered significant 
COMPARATIVE STUDY BETWEEN DEXAMETHASONE AND FENTA... 505

\section{RESULTS}

There were non significant difference sex, ASA and body weight variations between study groups as regards to age, (Table 1).

Table (1): Patients characterstics and duration of surgery in studied group

\begin{tabular}{|c|c|c|c|c|}
\hline \multirow{2}{*}{\multicolumn{2}{|c|}{ Grouns }} & $\begin{array}{c}\text { Dexamethasone } \\
\text { group } \\
\mathbf{N}=\mathbf{3 0} \\
\end{array}$ & $\begin{array}{c}\text { Fentanyl } \\
\text { group } \\
\mathbf{N}=\mathbf{3 0} \\
\end{array}$ & \multirow[t]{2}{*}{ P-value } \\
\hline & & Mean \pm SD & Mean \pm SD & \\
\hline \multirow{2}{*}{$\begin{array}{l}\text { Age } \\
\text { (years) }\end{array}$} & Mean \pm SD & $36.87 \pm 11.52$ & $35.80 \pm 10.75$ & \multirow[b]{2}{*}{$>0.05$} \\
\hline & Range & $18-60$ & $19-58$ & \\
\hline \multirow{2}{*}{ Sex } & Males & $23(76.7 \%)$ & $17(56.7 \%)$ & \multirow[b]{2}{*}{$>0.05$} \\
\hline & Females & $7(23.3 \%)$ & $13(43.3 \%)$ & \\
\hline \multirow{2}{*}{ ASA } & 1 & $23(76.7 \%)$ & $21(70.0 \%)$ & \multirow[b]{2}{*}{$>0.05$} \\
\hline & 2 & $7(23.3 \%)$ & $9(30.0 \%)$ & \\
\hline \multirow{2}{*}{ Weight } & Mean \pm SD & $77.97 \pm 5.85$ & $76.50 \pm 8.89$ & \multirow[b]{2}{*}{$>0.05$} \\
\hline & Range & $65-90$ & $58-90$ & \\
\hline
\end{tabular}

There were no significant difference between the study group (Table 2).

Table (2): Comparison of duration of surgery between the studied groups

\begin{tabular}{|l|c|c|c|}
\hline \multirow{2}{*}{$\begin{array}{l}\text { Guration of } \\
\text { surgery (min) }\end{array}$} & $\begin{array}{c}\text { Dexamethasone } \\
\text { group }\end{array}$ & \multirow{2}{*}{$\begin{array}{c}\text { Fentanyl } \\
\text { group }\end{array}$} & \multirow{2}{*}{ P-value } \\
\cline { 2 - 3 } & Mean \pm SD & Mean \pm SD & \\
\hline Mean \pm SD & $97.67 \pm 16.07$ & $96.17 \pm 18.08$ & \multirow{2}{*}{0.735} \\
\hline Range & $70-120$ & $60-120$ & \\
\hline
\end{tabular}

The onset of sensory block was faster in fentanyl group compared to dexamethasone group. A significant statically difference existed between two groups.The time of complete sensory block was shorter in fentanyl group compared to dexamethasone group. There was a statically high significant difference between groups. The duration of sensory block significantly prolonged in dexamethasone group compared to fentanyl group.Fentanyl group had the shorter time of onset compared to dexamethasone group. There was statically high significant difference between groups.Fentanyl group had the shorter time for complete of the block compared to dexamethasone group. There was statically high difference between groups. The duration of motor block was significantly prolonged in dexamethasone group compared to fentanyl group. There was a statically high significance difference (Table 3). 
Table (3): Sensory and motor criteria after drugs administration in the studied groups

\begin{tabular}{|c|c|c|c|}
\hline \multirow{2}{*}{$\begin{array}{c}\begin{array}{c}\text { Onset of } \\
\text { sensory block } \\
\text { (min) }\end{array} \\
\end{array}$} & $\begin{array}{l}\text { Dexamethasone } \\
\text { group }\end{array}$ & $\begin{array}{l}\text { Fentanyl } \\
\text { group }\end{array}$ & \multirow[t]{2}{*}{ P-value } \\
\hline & Mean \pm SD & Mean \pm SD & \\
\hline Mean \pm SD & $7.43 \pm 1.33$ & $6.57 \pm 1.45$ & \multirow{2}{*}{0.019} \\
\hline Range & $4-10$ & $4-10$ & \\
\hline \multirow{2}{*}{$\begin{array}{c}\text { Complete of } \\
\text { sensory block } \\
\text { (min) }\end{array}$} & $\begin{array}{l}\text { Dexamethasone } \\
\text { group }\end{array}$ & $\begin{array}{l}\text { Fentanyl } \\
\text { group }\end{array}$ & \multirow[t]{2}{*}{ P-value } \\
\hline & Mean \pm SD & Mean \pm SD & \\
\hline Mean \pm SD & $19.10 \pm 2.56$ & $16.57 \pm 2.65$ & \multirow{2}{*}{$<0.001$} \\
\hline Range & $14-24$ & $12-21$ & \\
\hline \multirow{2}{*}{$\begin{array}{l}\text { Duration of } \\
\text { sensory block } \\
\text { (h) }\end{array}$} & $\begin{array}{c}\text { Dexamethasone } \\
\text { group }\end{array}$ & $\begin{array}{c}\text { Fentanyl } \\
\text { group }\end{array}$ & \multirow[t]{2}{*}{ P-value } \\
\hline & Mean \pm SD & Mean \pm SD & \\
\hline Mean \pm SD & $19.00 \pm 1.80$ & $12.03 \pm 1.54$ & \multirow{2}{*}{$<0.001$} \\
\hline Range & $16-22$ & $9-16$ & \\
\hline \multirow{2}{*}{$\begin{array}{c}\begin{array}{c}\text { Onset of } \\
\text { motor block } \\
\text { (min) }\end{array} \\
\end{array}$} & $\begin{array}{c}\text { Dexamethasone } \\
\text { group }\end{array}$ & $\begin{array}{c}\text { Fentanyl } \\
\text { group }\end{array}$ & \multirow{2}{*}{ P-value } \\
\hline & Mean \pm SD & Mean \pm SD & \\
\hline Mean \pm SD & $6.10 \pm 1.12$ & $5.00 \pm 1.08$ & \multirow{2}{*}{$<0.001$} \\
\hline Range & $4-8$ & $4-8$ & \\
\hline \multirow{2}{*}{$\begin{array}{c}\begin{array}{c}\text { Complete of } \\
\text { motor block } \\
(\mathrm{min})\end{array} \\
\end{array}$} & $\begin{array}{l}\text { Dexamethasone } \\
\text { group }\end{array}$ & $\begin{array}{l}\text { Fentanyl } \\
\text { group }\end{array}$ & \multirow{2}{*}{ P-value } \\
\hline & Mean \pm SD & Mean \pm SD & \\
\hline Mean \pm SD & $23.47 \pm 2.67$ & $20.57 \pm 3.22$ & \multirow{2}{*}{$<0.001$} \\
\hline Range & $18-28$ & $15-28$ & \\
\hline \multirow{2}{*}{$\begin{array}{c}\text { Duration of } \\
\text { motor block } \\
\text { (h) }\end{array}$} & $\begin{array}{l}\text { Dexamethasone } \\
\text { group }\end{array}$ & $\begin{array}{l}\text { Fentanyl } \\
\text { group }\end{array}$ & \multirow{2}{*}{ P-value } \\
\hline & Mean \pm SD & Mean \pm SD & \\
\hline Mean \pm SD & $18.93 \pm 1.76$ & $11.73 \pm 1.72$ & \multirow{2}{*}{$<0.001$} \\
\hline Range & $16-22$ & $9-15$ & \\
\hline
\end{tabular}

The duration of analgesia was longer in dexamethasone group than the fentanyl group.There was statically high significant difference between group.There was no significant difference between study group in post operative pain (Table 4).

Table (4): Post operative analgesia and pain score in studied groups

\begin{tabular}{|c|c|c|c|}
\hline \multirow{2}{*}{$\begin{array}{l}\text { 1st analgesia } \\
\text { rescue }(h)\end{array}$} & $\begin{array}{c}\text { dexamethasone } \\
\text { group }\end{array}$ & $\begin{array}{l}\text { Fentanyl } \\
\text { group }\end{array}$ & \multirow[t]{2}{*}{ P-value } \\
\hline & Mean \pm SD & Mean \pm SD & \\
\hline Mean \pm SD & $19.37 \pm 1.92$ & $12.67 \pm 1.67$ & \multirow{2}{*}{$<0.001$} \\
\hline Range & $16-23$ & $10.2-17$ & \\
\hline \multirow{2}{*}{$\begin{array}{c}\text { Post-operative } \\
\text { pain } \\
\text { (numeric } \\
\text { Rating Scale) }\end{array}$} & $\begin{array}{c}\text { Dexamethasone } \\
\text { group }\end{array}$ & $\begin{array}{l}\text { Fentanyl } \\
\text { group }\end{array}$ & \multirow{2}{*}{ P-value } \\
\hline & Mean $\pm \mathrm{SD}$ & Mean \pm SD & \\
\hline Mean \pm SD & $3.83 \pm 0.53$ & $3.87 \pm 0.63$ & \multirow{2}{*}{0.825} \\
\hline Range & $3-5$ & $3-5$ & \\
\hline
\end{tabular}

All hemodynamic parameters were stable throughout the study with no complications. 


\section{DISCUSSION}

An effective, reliable block has shown to be provided by the application of US guided supraclavicular brachial plexus during upper extremity surgery, leading to a fewer complication, high satisfaction from patient and surgeon, reducing postoperative analgesia and longtime till the 1st analgesia request as well as less hospital stay and less financial burden.

A regional technique should always be considered whenever general condition of the patient is poor, or the patients is not adequately prepared or in the presence of associated condition like uncontrolled diabetes, hypertension, cardiovascular, or respiratory diseases. It is also useful when the patients prefers to retain his consciousness during surgery and when it is important for the patient to remain ambulatory.

Adjuvants or additives are often used with local anaesthetics for its synergistic effect by prolonging the duration of sensory-motor block, limiting the cumulative dose requirement of local anaesthetics and prolongation of duration of analgesia. The addition of additive to bupivacaine like fentanyl and dexamethasone enhanced the duration of post-operative analgesia till the analgesia request and leads to reduction in pain score in 1st 24hours post-operative (Swain et al, 2017).

In this study we aimed to compare the efficacy of fentanyl versus dexamethasone as adjuvants on block characteristics (onset and duration of sensory and motor blockade, duration of postoperative analgesia, post-operative pain score.
The current study showed that the addition of dexamethasone to bupivacaine for supraclavicular brachial plexus block leads to prolongation of motor and sensory block duration, prolongation of duration of analgesia, onset of motor and sensory block was shorter in fentanyl group than dexamethasone group.

Many studies had used dexamethasone as an adjuvant to LA in different regional and peripheral nerve blocks and found that it is an excellent choice in potentiating the local anesthetic effect. The safety of the perineural administration of dexamethasone has been well established in experimental studies. An animal study showed that perineural administration of dexamethasone up to $8 \mathrm{mg}$ had no effect on either nerve axons or myelin sheaths and might even attenuate the acute perineural inflammation induced by bupivacaine without causing nerve damage (Choi et al, 2014).

In humans, dexamethasone has been safely used up to $8 \mathrm{mg}$ in neuraxial blocks. We cautiously used a lower dose of dexamethasone in the present study. No neurologic deficit was observed in any patient receiving dexamethasone. Surprisingly, preliminary evidence seems to suggest that dexamethasone has potential for neuroprotection, especially when compared with lidocaine and bupivacaine. In our study, we found the addition of $8 \mathrm{mg}$ of dexamethasone to $20 \mathrm{ml}$ bupivacaine $(0.5 \%)$ significantly prolonged the block duration as well as analgesia duration this results met with Cummings et al. (2011).

De La Fuente and Altermatt. (2012) demonstrated that perineural dexamethasone (4 and $8 \mathrm{mg}$ ) significantly 
prolongs analgesia and motor block duration with $0.25 \%$ bupivacaine in supraclavicular brachial plexus nerve block. In addition, this study did not show statistically significant differences among different dosages of dexamethasone on analgesia duration and motor block prolongation. N.De La Fuente and F. R. Altermat, studied effects of $20 \mathrm{~mL}$ bupivacaine $(0.5 \%)$ on interscalene brachial plexus block in combination with 8-mg dexamethasone and without dexamethasone in control group and observed analgesia duration for 24.3 and 13.9 hours, respectively.

Vieira et al. (2010) conducted a similar study with $40 \mathrm{~mL} 0.5 \%$ bupivacaine and concluded that the duration of analgesia was significantly prolonged with 4-mg dexamethasone to 21.6 hours, $8-\mathrm{mg}$ dexamethasone to 25.2 hours, with the control group at 13.3 hours. In our study we have no control group.

Bani-Hashem et al. (2011), in their meta-analysis in Cochrane medical library, concluded low to moderate quality evidence suggest that the perineural and intravenous dexamethasone may prolonge the duration sensory block and are effective in reducing post-operative pain.

Shrestha et al. (2009) suggested in their study on dexamethasone and clonidine as an adjuvant to lignocaine $(1.5 \%)$ in infraclavicular brachial block the duration of block in dexamethasone group was longer than clonidine group.

On other side, Movafegh et al. (2010) did not observe any analgesic benefit in their patients who received dexamethasone with ropivacaine in ultrasound guided supraclaviular brachial plexus block. We suggested that the difference was due to use of long acting local anesthetic which masks the effect of dexamethasone.

In our study, the onset time of sensory and motor block delayed in dexamethasone group when compared to fentanyl group. This result met with Choi et al. (2014) who performed ultrasound guided interscalene brachial plexus block scheduled for shoulder arthroscopy using local anesthetic mixture with dexamethasone adjuvant. There was no significant reduction in onset of sensory and motor blockade in dexamethasone group compared to control group. This discrepancy could be due to the difference in the local anesthetic volume and technique of block.

In another study, Vieira et al. (2010) stated that dexamethasone, as adjuvant to bupivacaine in ultrasound guided supra clavicular block produced a relatively rapid onset of motor and sensory block.

Possible explanations mentioned by Yadav et al. (2010) were that it may be related to a degree of vasoconstriction occurred perineurally which results in a slow absorption of local anesthetics, suppression of the synthesis and secretion of inflammatory mediators, reducing the transmission in unmyelinated C-fiber, through immune-suppressive effects or local effect on the nerve. Ma et al. (2010) believed that analgesic properties of dexamethasone are the result of their systemic effect. Kumar et al. (2014) suggested local action on nerve fiber and systemic action both potentiate dexamethasone analgesic properties. 


\section{LIMITATIONS}

- First limitation of this study was small sample size.

- A second limitation was the inability to assess Fentanyl plasma concentration among study patients to determine whether its action was related to systemic absorption or pure local effect.

- A third limitation resulted from the fact that the beneficial effects of dexamethasone could be explained by its systemic absorption.

- A fourth limitation is limited availability and high price of Fentanyl

- A fifth limitation is inability to compare post-operative opioid consumption due to limited availability in outwards and routine use of NSAIDs.

\section{CONCLUSION}

The addition of dexamethasone to bupivacaine prolonged the time of block and analgesia duration longer than fentanyl. Also, the onset of block was shorter when fentanyl was added to bupivacaine.

\section{REFERENCES}

1. Bani-Hashem, N., Hassan-Nasab, B., Pour, E. A., Maleh, P. A., Nabavi, A. and Jabbari, A. (2011): Addition of intrathecal Dexamethasone to Bupivacaine for spinal anesthesia in orthopedic surgery. Saudi Journal of Anaesthesia, 5(4): 382-386.

2. Basin JE, Masson $C$, Bruelle $P$, Fenies $V$, Groslier D and Schoeffler P. (2012): The addition of opioids to local anesthetics in brachial plexus block: the comparative effects of morphine, buprenorphine and fentanyl. Anesthesia, 52:858-862.
3. Choi, S., Rodseth, R., and McCartney, C. J. L. (2014): Effects of dexamethasone as a local anaesthetic adjuvant for brachial plexus block: a systematic review and meta-analysis of randomized trials. British Journal of Anaesthesia, 112(3): 427-439.

4. Cummings III, K. C., Napierkowski, D. E., Parra-Sanchez, I., Kurz, A., Dalton, J. E., Brems, J. J. and Sessler, D. I. (2011): Effect of dexamethasone on the duration of interscalene nerve blocks with ropivacaine or bupivacaine, British Journal of Anaesthesia, 107(3): 446-453.

5. De la Fuente, N., and Altermatt, F. R. (2012): Adding dexamethasone to peripheral nerve blocks can give better postoperative analgesia. British Journal of Anaesthesia, 108 (1): 161-161.

6. El-Baradey, G. F. and Elshmaa, N. S. (2014): The efficacy of adding dexamethasone, midazolam, or epinephrine to $0.5 \%$ bupivacaine in supraclavicular brachial plexus block. Saudi Journal of Anaesthesia, 8 (Suppl 1): S78-85.

7. Kumar S, Palaria U, Sinha A, Punera D and Pandey V. (2014): Comparative evaluation of ropivacaine and ropivacaine with dexamethasone in supraclavicular brachial plexus block for Post-operative analgesia. Anaesth Essays Res, 8(2):202-08.

8. Laiq N, Khan MN, Arif M and Khan S. (2008): Midazolam with bupivacaine for improving analgesia quality in brachial plexus block for upper limb surgeries. J Coll Physicians Surg Pak, 18:674-678.

9. Ma, R., Wang, X., Lu, C., Li, C., Cheng, Y., Ding, G., and Ding, Z. (2010): Dexamethasone attenuated bupivacaineinduced neuron injury in vitro through a threonine-serine protein kinase B-dependent mechanism. Neuroscience, 167(2): 329-342.

10. Movafegh, A., Razazian, M., Hajimaohamadi, F., and Meysamie, A. (2010): Dexamethasone added to lidocaine prolongs axillary brachial plexus blockade, Anesthesia and Analgesia, 102 (1): 263-267.

11. Sari, S., Sen, S., Kurt Omurlu, I., Oner Şavk, S., and Bakiş, M. (2015): Degree of 
motor block measured by bromage scale is not correlated with muscle relaxation. Enliven: J Anesthesiol Crit Care Med, 2(2): 005 .

12. Shrestha B. R, Maharjan S. $K$ and Tabedar S. (2009): Supraclavicular brachial plexus block with and without dexamethasone a comparative study. Kathmandu University Medical Journal, 1 (3): 158-160.

13. Swain A, Nag DS, Sahu S and Samaddar DP. (2017): Adjuvant to local anesthesics:Current understanding and future trends. World J Clin Cases, 16,5(8):307-311.

14. Vieira PA, Pulai I, Tsao GC, Manikantan P, Keller B and Connelly NR. (2010): Dexamethasone with bupivacaine increases duration of analgesia in ultrasound-guided interscalene brachial plexus blockade. Eur $\mathbf{J}$ Anaesthesiol; 27: 285-288.

15. Yadav RK, Sah BP, Kumar $P$ and Singh SN. (2009): Effectiveness of addition of neostigmine or dexamethasone to local anaesthetic in providing perioperative analgesia for brachial plexus block: a prospective, randomized,double blinded, controlled study. Kathmandu Univ Med J, 6:302-309. 
COMPARATIVE STUDY BETWEEN DEXAMETHASONE AND FENTA... 511

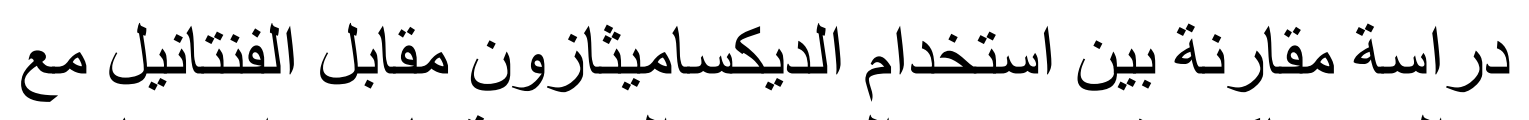

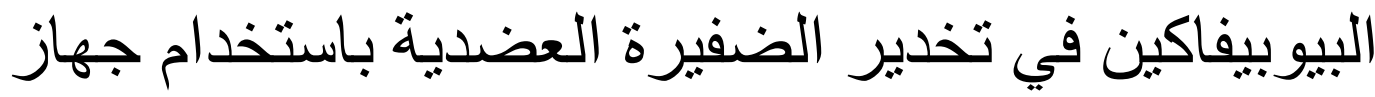
الموجات فوق الصوتية في جر احات الطرف فئفيرة العلوي

محسن بلوي سيد، سعيد مصطفي عبد الحميد، إسلام محمد يوسف أحمد

$$
\text { قسم التخديروالرعاية المركزة ـكلية طب الأزهر }
$$

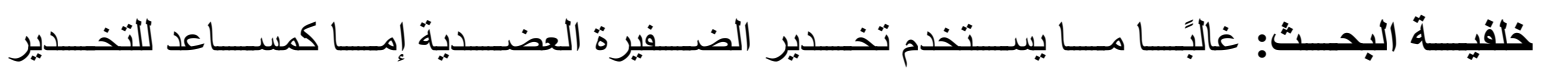

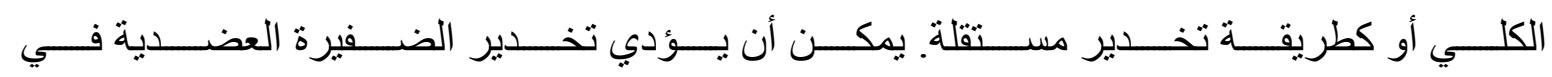

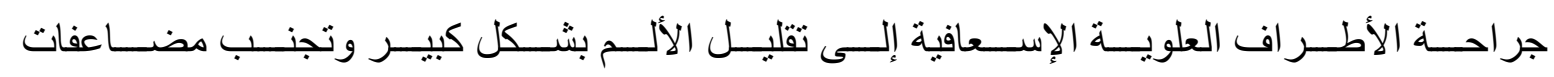

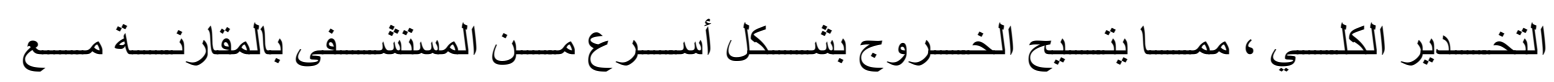

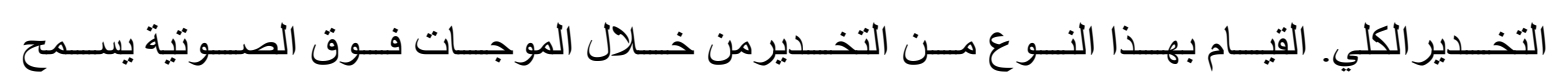

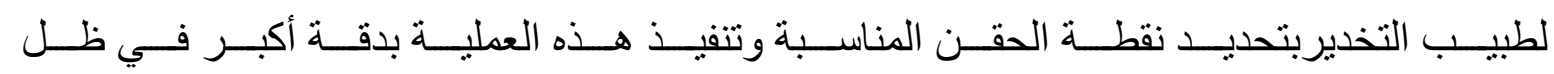
التصور المباثر.

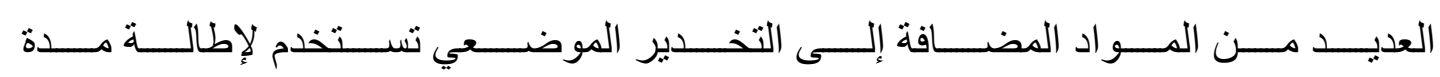

تسكين الكتل العصبية المحيطية.

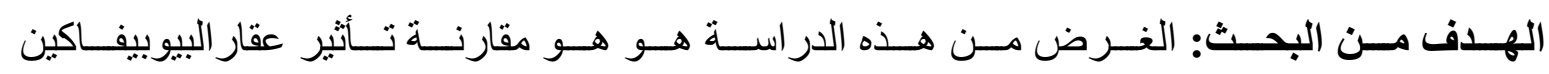

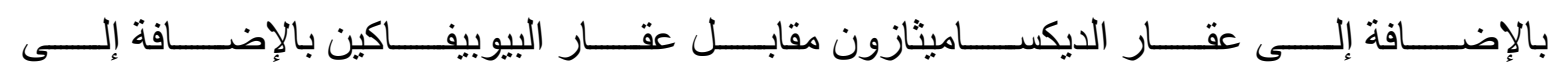

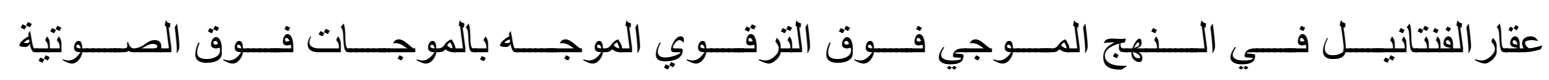
لتخدير الضفيرة العضدية لجر احة الأطر اف العلوية فيما يتعلق بما يلي: • بداية التخدير. • مدة التخدير. • ت تسكين ما بعد الجر احة.

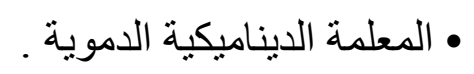

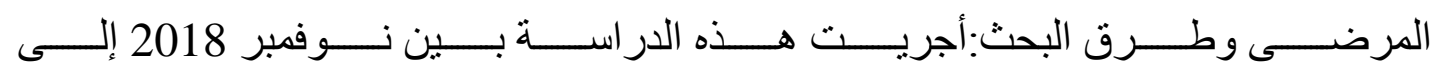

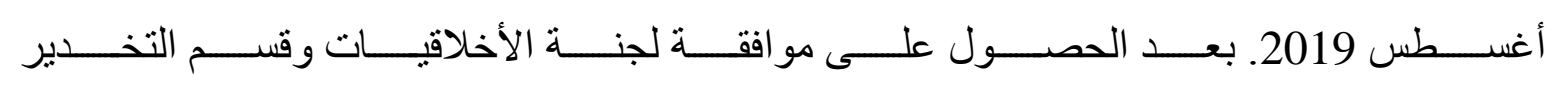




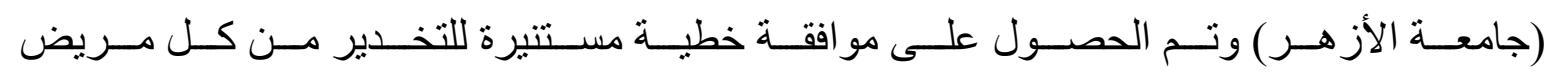
بعد أن أوضح لهم طبيعة الدراسة و المضاعفات.

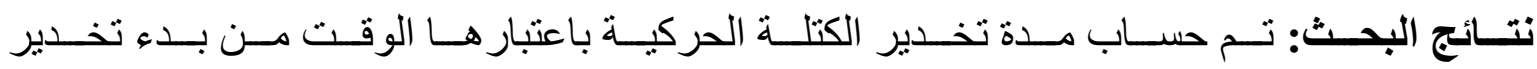

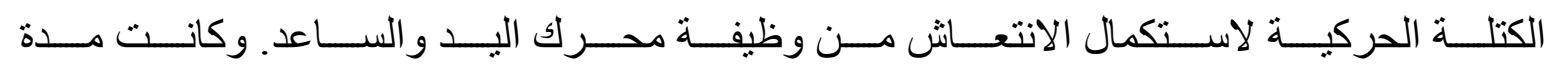

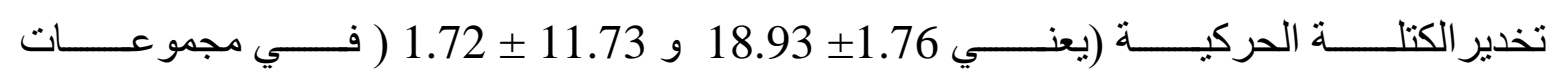
الديكساميثازون و الفنتانيل على التو الي.

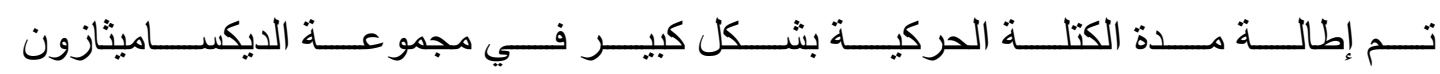

مقارنة بمجمو عة الفنتانيل.

كان هنالك فرق إحصائى كبير بين المجمو عتين.

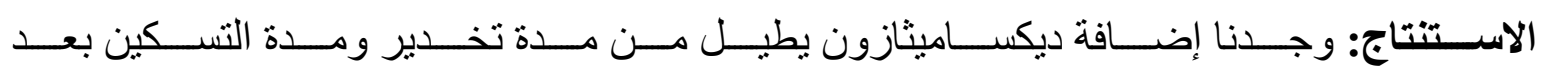

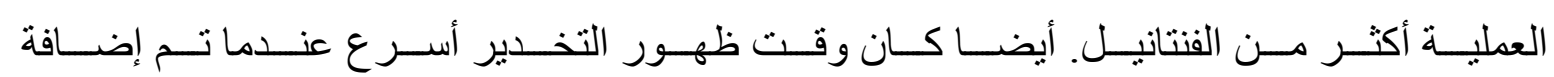
الفنتانيل. 